Università degli Studi di Salerno

Centro di Economia del Lavoro e di Politica Economica

Paolo Coccorese

Università di Salerno - CELPE

Banks as 'fat cats': Branching and Price Decisions in a Two-Stage Model of Competition

Corresponding author:

coccorese@unisa.it

Discussion Paper 118 
Scientific Commitee:

Adalgiso Amendola, Floro Ernesto Caroleo, Cesare Imbriani, Marcello D'Amato, Pasquale Persico

\section{C.E.L.P.E.}

Centro di Ricerca Interdipartimentale di Economia del Lavoro e di Politica Economica

Università degli Studi di Salerno

Via Ponte Don Melillo, 84084 Fisciano, I- Italy

http://www.celpe.unisa.it

E-mail: celpe@unisa.it 


\section{Index}

$\begin{array}{ll}\text { Abstract } & 5\end{array}$

Introduction $\quad 7$

1.Competition, banking and branching decisions: a review of the literature 9

2.The theoretical model 12

3.Empirical specification 17

4.Data and estimation 19

5.Conclusions 24

Appendix-Second-order conditions $\quad 25$

References $\quad 26$

Tables $\quad 29$

CELPE'S Discussion Paper 33 


\title{
Banks as 'fat cats': Branching and Price Decisions in a Two-Stage Model of Competition
}

\author{
Paolo Coccorese \\ Università di Salerno - CELPE
}

\begin{abstract}
In this paper we develop an empirical two-stage model of competition for the banking industry that incorporates the choice of capacity in the form of new branches. It is estimated using data on Italian banks for the years 1995-2009. The results show that the conduct of banks is significantly more competitive than a Bertrand-Nash equilibrium, and support the rejection of the simple one-stage specification, which underestimates the degree of competition. In the Fudenberg and Tirole (1984)'s taxonomy, banks are found to behave as 'fat cats', overinvesting in the branch network so as to keep prices high and accommodate entry.
\end{abstract}

Keywords: bank branch network; competition; market structure; conduct.

JEL Classification: G21, L10, L13 



\section{Introduction}

In this paper we formulate and estimate a structural model where banks compete in capacity and prices. Unlike the conventional models dealing with the market conduct of firms, which assume that either price or quantity are the only endogenous variables, we try to account also for the influence of an important capacity variable for banks - branch network - on the degree of product market competition.

Steps in this direction have been taken by authors who try to emphasize the interactions between competition in output market and specific input markets, such as R\&D, advertising, finance, labour, and capacity. For the purpose, they employ a two-stage set-up and evaluate the sensitivity of the estimated market power of firms to the introduction of these input variables. By making them endogenous, one can have a clearer idea about several interesting issues, for example the link between endogenous costs and market structure (Sutton, 1991), the optimal antitrust policy in presence of more than one strategic variable (Fershtman and Gandal, 1994), the possibility that endogenous capacity affects the conclusions about product market competition (Roller and Sickles, 2000), the effects that the degree of competition on the demand for inputs exert on competition in the product market (Neven et al., 2006), or the impact of labour supply augmenting investments when oligopsonistic firms set wages (Dewit and Leahy, 2009).

By means of a two-stage set-up, here we investigate whether introducing in the first stage decisions on the branch network (a capacity variable for banks) significantly influences the degree of banks' market power at the loan market level. If this is the case, a correct assessment of market power in banking industries would also require a careful consideration of properly endogenized input markets.

We test our model using data from the Italian banking sector in the years 1995-2009. The choice of the banking industry seems appropriate for at least three reasons. First, it is a fundamentally regulated industry because of its crucial role in the economy and the presence of notable informational problems, so a significant market power exists.

Secondly, in the last decades the banking markets of many European countries have undergone an intense consolidation process via mergers and acquisitions. Its origin lies especially in the introduction of the single currency, the reduction of cross-border barriers, and the development of the information and communication technologies (ICT). In Italy, a strong reorganization of the industry occurred as well (mainly in terms of deregulation and privatization of banks): the number of credit institutions reduced and their average size increased, while at the same time the number of branches remarkably grew. This generalized concentration wave pushes for an evaluation of whether the degree of competition among banks has changed.

Finally, the set up of brick and mortar bank branches is undoubtedly an important aspect of (non-price) competition among banks. They are long-run decisions that impose considerable (and usually sunk) costs on banks, while the choices on the interest rates concern the short run. However, in their lending activity banks need to gather information about resident clientele and local economic conditions, so as to evaluate the ability of customers to refund the money. Hence, the physical presence of branches appears unavoidable and to be maintained (Corvoisier and Gropp, 2007, p. 2).

The focus on the Italian context seems appropriate as well. As already mentioned, since the 1980s important transformations occurred in the Italian banking system, in order to foster market competition. Before 1978, credit authorities had followed a quite cautious attitude in evaluating whether to allow the establishment of new local bank offices, and their opening 
was subject to discretionary economic reasons, without any automatic procedure. After the approval of the First European Directive (1977), the Bank of Italy issued three 'branch distribution plans' $(1978,1982,1986)$, i.e. regulatory measures for the opening of new branches: they were intended to progressively relax the geographical restrictions on lending and lower the barriers to entry in local markets. Finally, in March 1990 the possibility of setting up new bank offices was fully liberalized.

Since then, there has been a noteworthy increase in the number of branches. They rose from 16,596 in 1990 to 34,036 in $2009(+105.1 \%)$, with outstanding growth rates in the period from 1990 to 2001 (see Table 1). This pattern characterized the whole country, with only slight differences among areas, and caused a notable transformation of the overall financial market. Still in the period 1990-2009, the loans to GDP ratio increased from $57.8 \%$ to $102.8 \%$, the share of municipalities with at least one branch from $62.9 \%$ to $73.1 \%$, the average number of branches per municipality from 2 to $4.2(+110 \%)$, the average number of branches per bank from 15.6 to $43.2(+176.9 \%)$, and the average number of branches per million inhabitants from 292.6 to 564.8 (+93\%).

In parallel with the growth of their average size, in the same period the number of Italian banks declined from 1064 to $788(-25.9 \%)$ as a result of the vigorous consolidation process due to the worldwide deregulation of capital markets, the harmonization of financial legislations (especially within EU), the fast ICT progress, and a generalized reduction of entry barriers.

Thus, it is crucial to carefully assess the degree of competition in the Italian banking sector: the heightened market concentration (caused by the reduction of the number of credit institutions) might have increased the market power of incumbent banks. Although previous studies for Italy (and for several other banking markets as well) have rejected this hypothesis, further investigations that account also for other factors - such as the optimal investment in the branch network - seem helpful for a clear understanding of the strategic choices of banks and their influence on the system as a whole. ${ }^{1}$

It is also worth noting that our approach is based on a robust theoretical background and, compared to other studies on the Italian banking sector (e.g. Cerasi et al., 2000, 2002), does not assume any predetermined market structure, since we are going to estimate an endogenous conjectural variation parameter that is able to categorize ex post the type of competition among banks.

The organization of the paper is the following. Section 2 reviews the literature on competition models and branching behaviour of banks. Sections 3 and 4 describe the theoretical model and its functional specifications for the banking industry, respectively. Section 5 discusses the data and the empirical results. Section 6 concludes.

\footnotetext{
${ }^{1}$ In spite of the sharp consolidation, the banking market concentration in Italy still remains relatively small compared to the other EU member countries: in 2009 the Herfindahl index for the Italian credit institutions (calculated on total assets) was 353, the lowest value in Europe after Germany and Luxembourg (ECB, 2010, p. 36).
} 


\section{Competition, banking and branching decisions: a review of the literature}

To assess the oligopoly conduct, latest empirical studies mostly employ the so-called 'new empirical industrial organization' (NEIO) approach, which relies on non-structural models inferring market power from the observation of firms' conduct and requiring the estimation of equations based on theoretical frameworks of price and output determination. More in depth, these models try to test conduct by directly addressing firms' behaviour through the estimation of a parameter that can be interpreted as a conjectural variation coefficient (Iwata, 1974; Appelbaum, 1979, 1982; Roberts, 1984) or as the deviation of the perceived marginal revenue schedule of a firm in the industry from the demand schedule (Bresnahan, 1982, 1989; Lau, 1982; Alexander, 1988). However, they generally consider only one strategic variable, usually price or quantity. ${ }^{2}$

NEIO techniques has been applied in banking markets by Shaffer $(1989,1993,2004)$, Berg and Kim (1994), Shaffer and DiSalvo (1994), Coccorese (1998, 2005, 2009), Neven and Roller (1999), Toolsema (2002), Angelini and Cetorelli (2003), Canhoto (2004), and Uchida and Tsutsui (2005). These studies cover different countries and provide some mixed evidence; however, imperfect competition in banking markets is the predominant and strongest result.

The investigation of interest margins and Lerner indices is a direct way to get information about the average mark-up of prices over costs, and therefore on banks' profitability. For example, Corvoisier and Gropp (2002) and Maudos and Fernandez de Guevara (2007) employ these measures for the European banking.

Price-based indicators of competition have been recently augmented with non-price measures of competitive behaviour, under the hypothesis that banks may substitute or complement them in certain instances (Carbo et al., 2009). Actually, in imperfect competition markets non-price strategies may help firms to differentiate themselves and thus extract market power. Among non-price competition devices, it is regarded as valuable to investigate firms' choice of capacity, which allows to account for strategic moves. Particularly, banks' branching decision is a foremost issue.

Branches represent the main interface between banks and clientele. Their territorial distribution is crucial for providing financial services, as they both collect deposits and grant loans. The branch network has also a decisive role in facilitating the provision and processing of information. It helps to obtain and handle borrower-specific information in local geographical areas, improving the overall quality of the loan portfolio. In this respect, Jayaratne and Strahan (1996) show that the relaxation of the US branching regulation has had an important role in the increase of the rate of real per capita growth in income and output, because branch network proliferation has improved loan monitoring and screening.

Setting up a brick and mortar branch is an investment that can secure profits in the future, but often represents a sunk cost for banks. It could be rewarding in areas where income is either high and expected to grow fast. On the other hand, in a competitive landscape profits can be hard to be precisely estimated, while the wrong choice of locating a branch in a given town or area is quite costly to modify. Hence, a bank that owns many branches in a region has much to lose and would be willing to deter entry; however, if markets are contestable this strategy is hard to be implemented, and one possibility is that incumbent banks saturate the

\footnotetext{
${ }^{2}$ For an exhaustive survey, see Bresnahan (1989).
} 
market with own branches, also considering the possibility of exploiting economies of scale due to the network effect.

As Gual (1999) notes, banks can compete through both interest rates and service quality. In the latter case, expanding the branch network may facilitate clients' access to the bank, thus improving customer service. Matching clientele's preferences over locations thus helps to mitigate interest rates competition. However, these two dimensions of competition are not independent: on the one hand, the larger the number of branches in a market, the tougher the competition on interest rates; on the other hand, the degree of competition on interest rates affects the incentive to expand the geographical presence, in order to get higher profits from a wider branch network (Cerasi et al., 2000, 2002).

This close relationship suggests the adoption of a model of bank behaviour that jointly considers the choices on interest rates and branching. Several studies on banks' behaviour concentrate on the importance of this form of non-price competition and its effects on banking markets.

Within a spatial competition model, Barros (1999) examines pricing decisions in the Portuguese commercial banking in presence of product differentiation induced by location in local markets. He concludes that the measurement of market power and the explanation of margins in the banking industry need to take into account the local market nature of the activity, and hence a deeper understanding of branching strategies and their interactions with price policies.

Pinho (2000) estimates a system of three equations for Portugal, where advertising expenditures and branches are regarded as non-price strategic variables, and finds that, while the combined effects of deregulation and reduced concentration have had a significant and positive impact on the use of advertising as a competitive instrument, no such effect is detected for branching expansion.

Kim and Vale (2001) consider the role of the branch network in the provision of loans in Norway, and estimate a model of branching decision where banks explicitly take account of both their own existing network and their expectation of rivals' choices. They set up a nonprice oligopolistic model of bank behaviour in the market for loans, at the same time analyzing the role of the branch network in banks' behaviour and testing the oligopolistic conduct in this sector. In their model, banks are able to consider rivals' future reaction to their own introduction of new branches, and the analysis provides evidence that banks are interdependent in their branching decisions, taking into consideration the future response from rival banks, and also that branching has a significant effect on banks' market shares, but not on the market demand.

Cerasi et al. (2002) employ a monopolistic competition model in order to measure branching costs and competitiveness for nine European banking industries, where banks are supposed to decide strategically the size of their branching network anticipating the degree of competition faced on interest rates. According to their results, the impact of the various European directives aiming at deregulating the banking industry has led to a general increase of the degree of competition.

Carbo et al. (2009) start from the Kim and Vale (2001)'s analysis and build a model where banks can compete with rivals in prices for deposits and loans as well as in branches. They fit this model to a sample of data for the Spanish banking system, and their results reveal that in Spain price competition has decreased in the loan market but has increased in the deposit market over the period 1986-2002, and also that the relative intensity of price versus non-price competition has varied over time. 
The choice about the location of de novo branches is one of the main strategic devices that Italian banks have employed in the last decades in order to face competition in the various provincial markets. ${ }^{3}$ In Italy the role of banks in the provision of funds is still decisive: since the average size of Italian firms is quite small, entrepreneurs are very dependent on banks for short-term credit and for funds which allow flexibility in responding to shocks (Calcagnini et al., 2002). Studies on banks' branching behaviour in Italy have become popular after the branch deregulation occurred in the late Eighties. De Bonis et al. (1998) prove that in the period 1990-1996 branch expansion has reduced concentration in provincial markets, but mergers have increased it at the national level. Calcagnini et al. (2002) propose a model that aims to explain the reasons for which Italian banks decide to open new branches in a province. It is estimated for the years 1992-1996 by means of a tobit regression, and shows that this choice is influenced by the existing market structure, the recent past branch expansion by the bank and its rivals, the past presence of the bank in the province, and the fact that many municipalities in the province are still unserved.

Cerasi et al. (2000) focus on the period 1989-1995, finding that the cost of opening branches has reduced, but the overall degree of competition of each local market has not significantly increased.

Estimating their monopolistic competition two-stage model for the years 1990-1996, Cerasi et al. (2002) find that for the Italian banks there are incentives for opening new branches, as marginal benefits of branching outweigh marginal costs.

Using data on 729 individual banks' lending in 95 Italian local markets over the period 19861996, Bofondi and Gobbi (2006) find that loan default rates are significantly higher for those banks that entered local markets without opening a branch. This means that having a branch on site may help to reduce the informational disadvantage.

Our analysis shares its basic features with the structural model developed by Roller and Sickles (2000) for the European airline industry. Using data for the period of 1976-1990, they have explicitly estimated a three-equation, two-stage structural model that considers competition in capacity and prices: particularly, in the first stage firms make capacity decisions, and a product-differentiated, price-setting game follows in the second stage. Estimation results show that higher investments in stage one induce a softer action by rival firms in stage two. Thus, they reject a simple one-stage specification in favour of a two-stage set-up, and find that some degree of market power in the product market exists, although it is significantly lower than in the one-stage model. In other words, firms' market power in the product market is significantly overestimated if capacity competition is not accounted for.

Neven et al. (2006) still consider the airline industry and estimate price-cost margins when firms bargain over wages. They implement a three-equation model using data for eight European airlines in the years 1976-1994, and show that the treatment of endogenous costs has important implications for the measurement of price-cost margins and the assessment of market power. In particular, their main results are that margins affect costs and vice versa, and that observed prices in Europe are virtually identical to monopoly prices only when costs are regarded as endogenous, even though observed margins are consistent with Nash behaviour.

An analogous theoretical background supports the study of Ma (2005), who develops a model in order to explain the excess capacity in the Taiwanese flour industry. Here an expected effect of a firm's first-stage investment on its rivals' outputs in the second stage is

\footnotetext{
${ }^{3}$ In Italy, the province (provincia) is an administrative district comprising a larger town or city and several little neighbouring towns. By and large, it corresponds to a U.S. county.
} 
introduced, and the empirical evidence is that a large capacity built in the first period can be used strategically to reduce other firms' outputs in the second period. This causes an overinvestment in the first stage and hence a misallocation of resources.

In what follows, we estimate a two-stage price-setting model for the Italian banking loan market: banks simultaneously decide whether to set up new branches (capacity) in the first stage, and then choose prices in the second stage. So, we treat capacity as an endogenous variable (determined in the first stage) that affects both production costs and market competition (in the second stage). This framework should allow to discover the effects of long-run capital investments from an individual bank on short-run price decisions.

\section{The theoretical model}

At year $t$, each bank faces the following demand for loans:

$$
q_{i t}=q_{i t}\left(p_{i t}, p_{j t}, Z_{i t}\right) \quad i=1, \ldots, N,
$$

where $N$ is the number of banks at year $t, q_{i t}$ is the quantity of loans demanded, $p_{i t}$ is the price of loans charged by bank $i, p_{j t}$ is an index of the rivals' prices, and $Z_{i t}$ is a vector of exogenous variables affecting loans.

The own-price effect on demand, $\partial q_{i t} / \partial p_{i t}$, and the cross-price effect on demand, $\partial q_{i t} / \partial p_{j t}$, are supposed to be negative and positive, respectively. The value of the latter is also expected to be high in case loans are considered as good substitutes across banks.

We assume that both short-run and long-run decisions on cost structure are able to affect banks' profitability. In the short run, costs (as well as demand and profits) are influenced only by variations in the price of output (loan rate) through $q_{i t}$; in the long run, banks can vary their cost structure also by means of changes in capacity (branches, here indicated as $B R_{i t}$ ). As a result, the long-run cost function is:

$$
C_{i t}^{L R}\left(q_{i}(\cdot), B R_{i t} \mid r_{i t}, \omega_{i t}\right)=C_{i t}^{S R}\left(q_{i t}(\cdot) \mid B R_{i t}, \omega_{i}\right)+r_{i t} B R_{i t}
$$

where $C_{i t}^{L R}(\cdot)$ and $C_{i t}^{S R}(\cdot)$ represent the long-run and the short-run specifications of the cost function, respectively. Short-run (variable) costs depend only on quantity, given a level of capacity $B R_{i t}$ and other input prices $\omega_{i t}$. In the long run, the level of capacity also becomes variable and can be purchased at its price $r_{i t}$.

In the second stage, each bank has to choose $p_{\text {it }}$ such that it maximizes the following profit function (we omit the subscript $t$ for convenience):

$$
\pi_{i}=q_{i}(\cdot) p_{i}-C_{i}^{S R}\left(q_{i}(\cdot) \mid B R_{i}, \omega_{i}\right)
$$

The corresponding first-order condition is:

$$
\frac{\partial \pi_{i}}{\partial p_{i}}=q_{i}+\left(p_{i}-M C_{i}\right)\left(\frac{\partial q_{i}}{\partial p_{i}}+\frac{\partial q_{i}}{\partial p_{j}} \frac{\partial p_{j}}{\partial p_{i}}\right)=0
$$


where $M C_{i}=\partial C_{i}^{S R} / \partial q_{i}$ is the short-run marginal cost.

Rearranging (4), we get:

$$
\frac{p_{i}-M C_{i}}{p_{i}}=-\frac{1}{\varepsilon_{i i}+\lambda \varepsilon_{i j} \frac{p_{i}}{p_{j}}}
$$

where $\varepsilon_{i i}=\frac{\partial q_{i}}{\partial p_{i}} \frac{p_{i}}{q_{i}}$ and $\varepsilon_{i j}=\frac{\partial q_{i}}{\partial p_{j}} \frac{p_{j}}{q_{i}}$ are the own-price elasticity and the cross-price elasticity of demand for loans, respectively, and $\lambda=\frac{\partial p_{j}}{\partial p_{i}}$ is the conjectural variation parameter of firm $i$. If correctly identified, $\lambda$ expresses the degree of coordination of banks. When $\lambda>0$, a bank expects the rivals will match its price, so cooperating in keeping revenues at a profitable level; perfectly collusive behaviour implies that $\lambda$ equals one. When $\lambda=0$, the behaviour foreshadows a Nash equilibrium in prices: each bank neither considers rivals' choices when setting its price, nor reacts when they change their behaviour. Finally, if $\lambda<0$, a bank wishing to increase its price expects the rivals to react competitively and therefore reduce their prices (Martin, 1993, p. 25): perfect competition requires that $\lambda=-\infty$, so that (5) turns into the wellknown $p=M C$ condition. In line with the relevant literature (e.g.: Farrell and Shapiro, 1990; Roller and Sickles, 2000), we assume that the conjectural variation is the same across all banks.

Let us indicate the solution of this (second-stage) maximization problem as $p_{i}{ }^{*}=p_{i}\left(B R_{i}, B R_{j}\right)$, where $B R_{j}$ represents the capacity choice of the other banks. Since capacity is committed before a bank chooses its price, the investment decision can be used strategically: one bank can influence rivals' prices through its choice of branches.

In the first stage, banks have to select the capacity level (branches) $B R_{i}$ that maximizes:

$$
\pi_{i}=q_{i}(\cdot) p^{*}{ }_{i}-C_{i}^{L R}\left(C_{i}^{S R}, B R_{i}\right)=q_{i}\left(p^{*}{ }_{i}, p^{*}, Z_{i}\right) p^{*}{ }_{i}-C_{i}^{S R}\left(q_{i}\left(p^{*}{ }_{i}, p^{*}, Z_{i}\right) \mid B R_{i}, \omega_{i}\right)-r_{i} B R_{i}
$$

The resulting first-order condition (where the superscript * is omitted for notational convenience) is:

$$
\frac{\partial \pi_{i}}{\partial B R_{i}}=q_{i} \frac{\partial p_{i}}{\partial B R_{i}}+\left(p_{i}-M C_{i}\right)\left(\frac{\partial q_{i}}{\partial p_{i}} \frac{\partial p_{i}}{\partial B R_{i}}+\frac{\partial q_{i}}{\partial p_{j}} \frac{\partial p_{j}}{\partial p_{i}} \frac{\partial p_{i}}{\partial B R_{i}}+\frac{\partial q_{i}}{\partial p_{j}} \frac{\partial p_{j}}{\partial B R_{i}}\right)-\frac{\partial C_{i}^{S R}}{\partial B R_{i}}-r_{i}=0
$$

We can now bring the first-order conditions of the two stages together. Particularly, we first derive $q_{i}$ from the optimality condition of stage 2 , i.e. (4), obtaining:

$$
q_{i}=-\left(p_{i}-M C_{i}\right)\left(\frac{\partial q_{i}}{\partial p_{i}}+\frac{\partial q_{i}}{\partial p_{j}} \frac{\partial p_{j}}{\partial p_{i}}\right)
$$

Then, we substitute (8) into (7). After some manipulations, we get: 


$$
\frac{\partial \pi_{i}}{\partial B R_{i}}=\left[-\frac{\partial C_{i}^{S R}}{\partial B R_{i}}-r_{i}\right]+\left(p_{i}-M C_{i}\right) \frac{\partial q_{i}}{\partial p_{j}} \frac{\partial p_{j}}{\partial B R_{i}}=0
$$

According to Fudenberg and Tirole (1984), the total effect of a capacity investment $B R_{i}$ by bank $i$ on its own profits can be decomposed into two effects. By changing $B R_{i}$, bank $i$ has a direct effect on $\pi_{\text {i }}$, i.e. $-\frac{\partial C_{i}^{S R}}{\partial B R_{i}}-r_{i}$, which is linked to the amount of the first-stage investment: more in depth, it depends on how short-run costs are affected by this investment as well as on the price of a unit of capacity. Clearly, this effect has no influence on the price of rival banks.

In addition, because of the two-stage specification there is also a strategic effect, i.e. $\left(p_{i}-M C_{i}\right) \frac{\partial q_{i}}{\partial p_{j}} \frac{\partial p_{j}}{\partial B R_{i}}$, which accounts for the influence of bank is capacity investment on the price of bank $j$ in the second stage. Whenever this strategic effect is zero, there is no need to specify a two-stage framework, and the sole direct effect is able to capture the impact of capacity decisions on profits (by way of a one-stage simultaneous-move price game). On the other hand, if the strategic effect does exist, the first-stage investment of bank $i$ can be used to strategically affect the other firms' choice in the second stage.

In our framework, the decision of bank $i$ to open a new branch depends on how this choice will affect its own profits (direct effect), but also on how the other competitors will react (strategic effect). Opening a new office affects bank is fixed costs because of the expenses it entails, but may have an additional (either positive or negative) effect on short-run costs, e.g. due to productive reorganisation or factor reallocation that a greater clientele can generate. Besides, it impacts on the other banks as well, given that it is likely to cause a migration of clients; the rivals could therefore react modifying their decision variable (here, price), which will affect in turn bank is demand and profits. ${ }^{4}$

The oligopolistic nature of banking markets should ensure that $p_{i}-M C_{i}>0$; furthermore, by definition it is $\partial q_{j} / \partial p_{j}>0$. As a result, the existence and the sign of the strategic effect depend on the term $\partial p_{j} / \partial B R_{i}$.

Since in the second stage banks compete in prices, choice variables are strategic complements. If $\partial p_{j} / \partial B R_{i}<0$, an increase in $B R_{i}$ causes a drop in both $p_{j}$ and $\pi_{i}$ : in Fudenberg and Tirole (1984)'s terminology, the investment in capacity makes banks 'tough', and they must adopt a 'puppy dog' strategy, i.e. underinvest in capacity if they want to look non-aggressive rivals. If $\partial p_{j} / \partial B R_{i}>0$, an increase in $B R_{i}$ produces an increase in both $p_{j}$ and $\pi$; now the investment in capacity makes banks 'soft', so that they need to adopt a 'fat cat' strategy, i.e. overinvest in capacity in order to look non-threatening rivals.

Thus, assessing the value and significance of $\partial p_{j} / \partial B R_{i}$ is crucial for understanding the right formulation of the game. Should it be zero, the strategic variable (capacity) of stage 1 does not affect the choices of stage 2, and there would be no need to specify a two-stage game because banks make simultaneous choices. In the opposite case, a two-stage set-up becomes necessary.

Starting from (4), we derive the following expressions:

\footnotetext{
${ }^{4}$ In their model, Cerasi et al. (2002) discuss of an 'expansive effect' and a 'competitive effect' that are linked to the decision to open branches.
} 


$$
\frac{\partial^{2} \pi_{i}}{\partial p_{i} \partial B R_{i}}=\frac{\partial p_{i}}{\partial B R_{i}}\left[\Delta_{i}\left(1-\frac{\partial M C_{i}}{\partial q_{i}} \Delta_{i}\right)+\Delta_{i}\right]+\Delta_{j} \frac{\partial p_{j}}{\partial B R_{i}}\left(1-\frac{\partial M C_{i}}{\partial q_{i}} \Delta_{i}\right)-\Delta_{i} \frac{\partial M C_{i}}{\partial B R_{i}}=0
$$

and

$$
\frac{\partial^{2} \pi_{i}}{\partial p_{i} \partial B R_{j}}=\frac{\partial p_{i}}{\partial B R_{j}}\left[\Delta_{i}\left(1-\frac{\partial M C_{i}}{\partial q_{i}} \Delta_{i}\right)+\Delta_{i}\right]+\Delta_{j} \frac{\partial p_{j}}{\partial B R_{j}}\left(1-\frac{\partial M C_{i}}{\partial q_{i}} \Delta_{i}\right)=0
$$

where $\Delta_{i}=\frac{\partial q_{i}}{\partial p_{i}}+\frac{\partial q_{i}}{\partial p_{j}} \frac{\partial p_{j}}{\partial p_{i}}=\frac{\partial q_{i}}{\partial p_{i}}+\frac{\partial q_{i}}{\partial p_{j}} \lambda$ is the own-demand effect that includes the conjectural variation (with $\Delta_{i}<0$ ), and $\Delta_{j}=\frac{\partial q_{i}}{\partial p_{j}}$ is the cross-demand effect (hence, $\Delta_{j}>0$ ).

Assuming symmetry, i.e. $\frac{\partial p_{i}}{\partial B R_{j}}=\frac{\partial p_{j}}{\partial B R_{i}}$ and $\frac{\partial p_{j}}{\partial B R_{j}}=\frac{\partial p_{i}}{\partial B R_{i}}$, from (10b) we obtain

$$
\frac{\partial p_{j}}{\partial B R_{i}}=\frac{\Delta_{j} \frac{\partial p_{i}}{\partial B R_{i}}\left(\frac{\partial M C_{i}}{\partial q_{i}} \Delta_{i}-1\right)}{\Delta_{i}\left(2-\frac{\partial M C_{i}}{\partial q_{i}} \Delta_{i}\right)}
$$

Substituting (10c) into (10a) leads to:

$$
\frac{\partial p_{i}}{\partial B R_{i}}=\frac{\partial M C_{i}}{\partial B R_{i}} \Delta_{i} \frac{A}{A^{2}-B^{2}}
$$

and

$$
\frac{\partial p_{j}}{\partial B R_{i}}=\frac{\partial M C_{i}}{\partial B R_{i}} \Delta_{i} \frac{B}{A^{2}-B^{2}}
$$

where $A=\Delta_{i}\left(2-\frac{\partial M C_{i}}{\partial q_{i}} \Delta_{i}\right)=\frac{\partial^{2} \pi_{i}}{\partial p_{i}^{2}}$ is the second-order condition for $p_{i}$ to be a local maximum (see also the Appendix), and $B=\Delta_{j}\left(\frac{\partial M C_{i}}{\partial q_{i}} \Delta_{i}-1\right)=-\frac{\partial^{2} \pi_{i}}{\partial p_{i} \partial p_{j}}$ is the negative of the cross-partial derivative of bank is profit function, i.e. the derivative of bank is marginal profit with respect to rivals' price.

Note that $A<0$ (each bank's profit function needs to be strictly concave in its own prices) and $B<0$ (the cross-partial derivative of each bank's profit function must be positive in case of strategic complements, like prices, which means that the reaction functions are upward sloping).

As $\Delta_{i}<0$, it is straightforward that $\operatorname{sign}\left\{\partial M C_{i} / \partial B R_{i}\right\}=\operatorname{sign}\left\{\partial p_{i} / \partial B R_{i}\right\}=\operatorname{sign}\left\{\partial p_{j} / \partial B R_{i}\right\}$. Therefore, when $\partial p_{j} / \partial B R_{i}<0$ it is also $\partial M C_{i} / \partial B R_{i}<0$, meaning that an increase in $B R_{i}$ 
pushes marginal costs downwards, while they move upwards in case $\partial M C_{i} / \partial B R_{i}>0$ and $\partial p_{j} / \partial B R_{i}>0$.

Roller and Sickles (2000) emphasize that the sign of $\partial M C_{j} / \partial B R_{i}$ - and hence of $\partial p_{j} / \partial B R_{i}-$ is able to indicate the direction of the bias that characterizes the conduct parameter $\lambda$ in case a two-stage formulation is not used.

In particular, in a two-stage 'puppy dog' game $\left(\partial M C_{i} / \partial B R_{i}<0\right)$ the capacity investment lowers $M C_{i}$ and $p_{i}$, but marginal costs decline more than prices (as the second-order condition of stage 1 requires that $\partial M C_{j} \partial B R_{i}<\partial p_{i} / \partial B R_{i}$ : see Appendix), so that a larger price-cost margin is associated to the same $\lambda$; this implies that a one-stage game would ignore this effect, leading to an upward bias in the measurement of market conduct (actually, for a lower pricecost margin there should be a lower $\lambda$ ).

When dealing with a two-stage 'fat cat' game $\left(\partial M C_{i} / \partial B R_{i}>0\right)$, an increase in $B R_{i}$ causes marginal costs to increase more than prices (in this case, it must be $\partial M C_{i} / \partial B R_{i}>\partial p_{i} / \partial B R_{i}$ : see Appendix), implying that a smaller price-cost margin is associated with a given $\lambda$; therefore, a one-stage game would result in a downward bias in the value of the conduct parameter (a higher price-cost margin would require a higher $\lambda$ ).

Of course, if $\partial M C_{i} / \partial B R_{i}=0$ no bias exists.

However, all the above is true for any $\lambda>0$. When $\lambda<0$, i.e. when conduct is more competitive than a Nash behaviour, the reverse reasoning applies. Actually, when $\partial M C_{i} / \partial B R_{i}<0$ the price-cost margin is larger in case of a one-stage game, and it lowers only when $\lambda$ increases (or also, when the absolute value of $\lambda$ decreases): in this instance, therefore, market conduct is underestimated. Conversely, for $\partial M C_{i} / \partial B R_{i}>0$, there will be an overestimation of the degree of market power.

Therefore, the remark of Roller and Sickles (2000, p. 853 ) needs to be reformulated as follows.

Proposition 1. Whenever the capacity game can be categorized as a 'puppy dog' (i.e. $\partial M C_{i} / \partial B R_{i}<0$ ), then a one-stage game would result in an upward bias in the measurement of market conduct if $\lambda>0$, and to a downward bias if $\lambda<0$. Whenever the capacity game can be categorized as a 'fat cat' (i.e. $\left.\partial M C_{i} / \partial B R_{i}>0\right)$, then a one-stage game would result in a downward bias in the measurement of market conduct if $\lambda>0$, and to a upward bias if $\lambda<0$. Finally, whenever $\partial M C_{i} / \partial B R_{i}=0$, no bias exists.

Estimating the two-stage model requires the simultaneous estimation of Equations (1), (5) and (9). By considering only Equations (1) and (5), one would implicitly assume that investments in capacity are exogenous (i.e. a one-stage set-up), at the same time getting a biased estimation of the conduct parameter $\lambda$ whenever $\partial p_{j} / \partial B R_{i} \neq 0$.

\section{Empirical specification}

In our three-equation model, the demand is the following:

$$
\ln q_{i t}=a_{1} \ln p_{i t}+a_{2} \ln p_{j t}+a_{3} \ln G D P_{i t}+a_{4} \ln B R S H A R E_{i t}+a_{5} t+\gamma_{i}+\tau_{i t}
$$


where $\tau$ is the error term. The dependent variable $q_{i t}$ is the amount of loans of bank $i$ at year $t$. Among the exogenous variables, we include bank is loan rate $\left(p_{i t}\right)$, a weighted average of rivals' loan rates $\left(p_{j t}\right)$, a measure of Gross Domestic Product that takes into account the regional distribution of bank i's branches $\left(G D P_{i t}\right)$, the share of branches that bank $i$ manages in the country $\left(B R S H A R E_{i t}\right)$, and a time trend $t$. In order to capture other possible characteristics of banks that do not change over time and affect the demand for loans, we also add a dummy $\gamma_{i}$ for each bank in the sample.

For all banks, $p_{i t}$ is calculated as the ratio between interest revenues and customer loans, while $p_{j t}$ has been built starting from the regional loan rates (as provided by the Bank of Italy), each weighted by the number of branches of bank $i$ in that region. A similar procedure has been used for the level of GDP, which is inserted as a proxy for aggregate demand. Finally, $B R S H A R E$ allows to take into account the size of banks' branch network. ${ }^{5}$ Apart from $p_{i t}$, all the above variables are expected to be positively correlated with loans.

The second equation of the model corresponds to the first-order condition of stage 2 :

$$
\frac{p_{i t}-M C_{i t}}{p_{i t}}=-\frac{1}{a_{1}+\lambda a_{2} \frac{p_{i}}{p_{j}}}+\varphi_{i t}
$$

where $\varphi$ is the error term, $a_{1}$ and $a_{2}$ are the own-price and the cross-price elasticities, respectively, as derived from Equation (1a), and $M C_{i t}$ is the (linear) short-run marginal cost, specified as:

$$
M C_{i t}=\frac{\partial C_{i t}^{S R}}{\partial q_{i t}}=b_{0}+b_{1} B R_{i t}+b_{2} \omega_{1 i t}+b_{3} \omega_{2 i t}+b_{4} E M P L B R_{i t}+b_{5} P R O V P R E S_{i t}+b_{6} t
$$

It is assumed to be dependent on branches $\left(B R_{i t}\right.$, the capacity variable), two factor prices namely, deposits $\left(\omega_{1 i t}\right.$, calculated as the ratio between interest expenses and customer deposits) and labour ( $\omega_{2 i t}$, given by the ratio between personnel expenses and the number of employees) - and two other characteristics that are supposed to affect short-run costs: the number of employees per branch $\left(E M P L B R_{i t}\right)$ and the percentage of provinces where the bank owns at least one branch (PROVPRES $\left.{ }_{i t}\right)$. A time trend is also added.

The variable $E M P L B R_{i t}$ is used as a measure of service quality (and therefore to account for service competition). Actually, more workers per branch should ensure a more accurate service for customers, because they allow shorter waiting times and foster valued human interactions (Dick, 2007, p. 64). The expected sign of this variable is however unpredictable: a higher ratio could allow an expansion of the amount of loans per worker (because of the better quality), but also impose more costs to the branch if this business growth is not enough.

The share of provinces in which the bank operates, PROVPRES it, should capture the level of geographic diversification: being linked to the size of the overall bank network - hence to the convenience to the consumer - this attribute has been already found to significantly affect the customer's choice of a bank (Dick, 2008). For this reason, it should have a favourable impact on costs, and therefore be negatively correlated with marginal costs.

\footnotetext{
${ }^{5}$ Note that BRSHARE can be regarded as an exogenous variable (unlike $B R$ ), since it depends on the choices of all banks operating in the industry at any given year.
} 
Substituting (12) into (5a) yields

$$
\frac{p_{i t}-\left(b_{0}+b_{1} B R_{i t}+b_{2} \omega_{1 i t}+b_{3} \omega_{2 i t}+b_{4} E M P L B R_{i t}+b_{5} P R O V P R E S_{i t}+b_{6} t\right)}{p_{i t}}=-\frac{1}{a_{1}+\lambda a_{2} \frac{p_{i}}{p_{j}}}+\varphi_{i t}
$$

The third equation to be estimated within our two-stage model is the first-order condition of stage 1 , as rearranged in (9) so as to consider also the optimality condition of stage 2 and emphasize both the direct and the strategic effect of a capacity investment:

$$
\left[-\frac{\partial C_{i t}^{S R}}{\partial B R_{i t}}-r_{i t}\right]+\left[\left(p_{i t}-M C_{i t}\right)\left(a_{2} \frac{q_{i t}}{p_{j t}}\right) \alpha\right]+\phi_{i t}=0
$$

where $\phi$ is the error term. The price of capital $r_{i t}$ is computed dividing all the operating costs different from those related to deposits and labour by the number of branches. $M C_{i t}$ is again given by (12), while the term $a_{2} \frac{q_{i t}}{p_{j t}}$ corresponds to $\frac{\partial q_{i}}{\partial p_{j}}$ as calculated from (1a). Finally, the parameter $\alpha=\frac{\partial p_{j}}{\partial B R_{i}}$ plays a key role in the whole model, as its estimated value (and significance) will indicate if the two-stage formulation of this game is correct.

The effect of adding capacity $\left(B R_{i t}\right)$ to the short-run costs, $\frac{\partial C_{i t}^{S R}}{\partial B R_{i t}}$, is supposed to work as follows:

$$
\frac{\partial C_{i t}^{S R}}{\partial B R_{i t}}=c_{0}+c_{1} q_{i t}+c_{2} B R F Q L O A N_{i t}+c_{3} B R P O P_{i t}+c_{4} t
$$

It is presumed linear in the level of output, $q_{i t}$, and other two characteristics measuring the potential productivity of capital: the percentage of each bank's branches that are located in those provinces that belong to the first quartile of the loans distribution over the country $\left(B R F Q L O A N_{i t}\right)$, and the number of branches per million of inhabitants $\left(B R P O P_{i t}\right)$. A time trend is again included.

The variable BRFQLOAN takes into account the geographical location of branches: if a higher share of local offices operates in areas where loan contracts are frequent, the same resources needed for some inputs (e.g. labour or running costs) should generate more lending activity, with a beneficial impact on costs; as a result, the sign of the related coefficient is expected to be negative.

The variable $B R P O P$ is used as a proxy for branch density: it is likely that more branches per each million of inhabitants guarantee more business, but they should also impose higher costs on banks. Hence, we expect a positive coefficient for this variable.

We can substitute (12) and (13) into (9a), getting 


$$
\begin{gathered}
{\left[-\left(c_{0}+c_{1} q_{i t}+c_{2} \text { BRFQLOAN }_{i t}+c_{3} \text { BRPOP }_{i t}+c_{4} t\right)-r_{i t}\right]+} \\
+\left[p_{i t}-\left(b_{0}+b_{1} B R_{i t}+b_{2} \omega_{1 i t}+b_{3} \omega_{2 i t}+b_{4} E{ }^{2} P L B R_{i t}+b_{5} P R O V P R E S_{i t}+b_{6} t\right)\right]\left(a_{2} \frac{q_{i t}}{p_{j t}}\right) \alpha+\phi_{i t}=0
\end{gathered}
$$

To sum up, we estimate a system of three equations: (1a), (5b) and (9b). As Roller and Sickles (2000) note, estimating a two-equation system with the demand function and the firstorder condition of stage 2 (i.e. with capacity investment treated as exogenous) could introduce potential simultaneity bias and lead to less efficient estimates; additionally, introducing the first-order condition of stage 1 as a third equation where the strategic twostage set-up is however ignored could imply its misspecification.

We use nonlinear three-stage least squares, thus endogenizing banks' capital stock $\left(B R_{i}\right)$, output $\left(q_{i}\right)$ and price $\left(p_{i}\right)$, and securing precise and efficient estimates, which are further improved by the simultaneous estimation of the three equations and the various crossequation restrictions. Because of the endogeneity of $B R_{i}, q_{i}$ and $p_{i}$, we use their first and second lagged values as instruments, together with the lagged values of $p_{j}$ at $t-1$ and $t-2$, in order to deal with possible problems of correlation between these variables and the error terms. We also include all the exogenous variables as instruments, together with banks' total assets, time trend and bank dummies.

\section{Data and estimation}

Our banks' income statement and balance sheet figures are drawn from ABI Banking Data, the database managed by the Italian Banking Association, and cover the period 1995-2009.

Given that this study aims to incorporate the capacity decisions of banks and their impact on rivals, we need to consider sizeable credit institutions that operate in geographically large areas. As a consequence, for each year we have selected only those banks whose size was classified either as "main", "big" or "medium" by the Central Bank of Italy. Furthermore, we have dropped banks whose absolute percentage variation of branches with respect to the previous year exceeds 50\%: this allows to keep the capacity choices separate from other operations like mergers, acquisitions or reorganizations.

After this screening, we have been left with 1417 observations regarding 117 banks. Table 2 reports some descriptive statistics of the sample. Official data on the geographical distribution of branches and loans, as well as regional data on loan rates, come from the Bank of Italy, while the information regarding GDP and population are made available by ISTAT (the Italian National Institute of Statistics). All economic figures have been deflated using the GDP deflator with 2000 as the base year.

We estimate our model for the whole sample, as well as for two geographical sub-samples (North vs. Center and South) and for the group of largest banks, identified as those having branches in at least a half of the 20 Italian regions. The results of system estimations are shown in Table 3. When not otherwise specified, our reference estimation will be the one regarding the whole sample of banks (first column of Table 3 ).

As expected, in the demand equation the coefficients of $p_{i}$ and $p_{j}$ have always a negative and positive sign, respectively, and are statistically significant at the $1 \%$ level. This confirms a downward-sloping demand function as well as a positive cross-price elasticity for loans.

The (relatively) small own-price elasticity, $a_{1}$, suggests that for customers loans have poor substitutes. Since a monopolistic firm sets its price on the elastic portion of the demand 
function, we deduce that banks are generally able to exercise their market power only to a little extent in their respective market niches.

The cross-price elasticity, $a_{2}$, is generally larger than the absolute own-price elasticity (this does not happen for the North). However, we can reject the hypothesis that $\left|a_{1}\right| \geq a_{2}$ only for Central and Southern regions and for the group of the largest banks: in these sub-samples, the fact that loans appear to be more sensitive to variation in $p_{j}$ rather than in $p_{i}$ indicates that they are regarded as good substitutes across banks, a signal of a considerable level of competition among credit institutions.

Turning to the whole sample, the absolute own-demand effect $\Delta_{i}$ is only slightly lower than the cross-demand effect $\Delta_{j}(-679.7 \mathrm{vs} .+741.3)$. Overall, the fact that the output of a bank is affected by an own-price change in a broadly similar way as by a rival's price change further confirms the good degree of competitiveness of the loan market in the period under investigation.

The variable GDP has a positive and statistically significant coefficient. However, its impact on loans is not particularly high: a one percent growth in the level of GDP of the areas where banks operate causes a $0.51 \%$ increase in their loan demand. The coefficient of BRSHARE is also positive and significant, suggesting that a larger size of the branch network, and hence a widespread presence over the territory, guarantees a larger demand for loans. The effect of time on loans is significant, and points to an increase in their demand during years.

Regarding the short-run marginal cost (stage 2 ), $b_{1}$ is positive and significant at the $1 \%$ level in two over four regressions. In these samples, there is evidence that the number of branches (i.e. capital) has a positive effect on $M C$ : adding capacity causes an increase in marginal costs of production. However, we shall discuss this later on.

The prices of deposits and labour appear not to affect marginal costs in the reference model. On the contrary, in Northern regions the first price exhibits a negative and significant coefficient. One explanation for this result is that deposits are characterized by a high degree of factor substitution, so that banks react to an increase in their prices by shifting to other inputs that are less costly (Neven and Roller, 1999, p. 1070).

In two over four regressions, the ratio between employees and branches (EMPLBR) is found to significantly lower marginal costs. This should mean that more labour-intensive offices are better managed and, all else equal, impose less costs as loans increase, possibly because their better service quality provides access to larger flows of both new and existing customers.

The coefficient related to the provincial presence (PROVPRES) is also negative but is again significant only in two models: here, as expected, banks with a wider geographic diversification are characterized by lower marginal costs.

Finally, short-run marginal costs show a downward trend over time only for the whole sample.

The value of the conjectural parameter $\lambda$ is negative and highly significant in all regressions. It amounts to -0.17 in the reference model. ${ }^{6}$ As a result, we are able to reject the hypothesis that there is monopoly power or coordination among the Italian banks. Quite to contrary, their behaviour appears to be more competitive than in a Bertrand-Nash equilibrium in prices. The above estimated value means that, if bank $i$ increases its loan market rate by, say, $10 \%$ with respect to the previous value, it expects that rivals will react by lowering their rate by $1.7 \%$,

\footnotetext{
${ }^{6}$ Our findings are in line with Coccorese (2005), who gets negative conjectural parameters for the Italian banking sector.
} 
while in a Bertrand-Nash game they would have left it unchanged, and in a cooperative framework they would have raised it as well. ${ }^{7}$ This outcome is comparable with the evidence of other studies that have investigated the market power of Italian credit institutions in analogous periods of time. ${ }^{8}$ Actually, many of them suggest that monopolistic competition is the best description of the Italian banking industry. ${ }^{9}$

By means of the right-hand side of Equation (5b), we can calculate the average mark-up over marginal costs, which amounts to $108.6 \%$ for the whole sample. Given that the BertrandNash behaviour $(\lambda=0)$ would imply a mark-up of $132.8 \%$ (and even higher values in case of monopolization), pricing in the Italian banking market appears rather competitive.

It is worth noting that the value of the conjectural parameter notably differs within the country. Competition appears stronger in the North $(-0.29)$ than in the Center and South of Italy ($0.11)$. Once more, it turns out that in Italy less wealthy regions are characterized by a lower degree of banking competition (Coccorese, 2004, 2008).

As for the marginal cost of capital (stage 1), parameter estimates are generally significant. This type of cost increases as the level of output $(q)$ grows: more loans are therefore coupled with higher expenditures for branches (however, this does not happen for Central and Southern regions).

The coefficient of BRFQLOAN is negative, confirming that marginal costs are lower for banks whose branches are mainly located where the volume of the demand for loans is more considerable. This parameter is not significant only for the biggest banks, probably because all of them do operate in the most central areas.

In contrast, the positive sign of BRPOP means that more branch offices per inhabitant raise the marginal cost of capital. Finally, the time trend captures an increase in this type of costs for the years under consideration (except for the largest banks, for which the marginal cost of capital appears to have decreased).

One key aspect of this analysis is to assess whether a two-stage formulation of the competition model is correct (and also desirable). To this purpose, we need to study the effect of capital (i.e. branches) on short-run marginal costs. As observed beforehand, the coefficient of $B R$ in the short-run marginal cost equation $\left(b_{1}\right)$ is always positive, and also significant at the $1 \%$ level in two over four models; in addition, the estimated coefficient of the variable $\alpha=\partial p_{j} / \partial B R_{i}$ is also positive and highly significant in all specifications. This evidence is in line with our expectations, as earlier we have demonstrated that it must be $\operatorname{sign}\left\{\partial M C_{i} / \partial B R_{i}\right\}=\operatorname{sign}\left\{\partial p_{j} / \partial B R_{i}\right\}$. Besides, the (high) significance of the above coefficients makes clear that the capacity variable of stage 1 has a major impact on the choices of the following stage. So, the one-stage specification must be rejected in favour of a two-stage model.

The positive sign of both $b_{1}$ and $\alpha$ suggests that setting up new branches makes banks 'soft': they overinvest in capacity in order to be less aggressive. Thus, they follow a 'fat cat' strategy. The intuition behind this result appears quite interesting, and can be explained as follows. When the Bank of Italy deregulated the branch opening all over the country in 1990, making much easier to get the relevant authorizations, incumbent banks realized that new

\footnotetext{
${ }^{7}$ On the contrary, Carbo et al. (2009) find evidence of a strong matching behaviour in terms of price competition for the Spanish banking industry in the period 1986-2002, being the value of the estimated conjectural variation parameters positive and significant.

${ }^{8}$ Among others, see Coccorese (2005) and van Leuvensteijn et al. (2007).

${ }^{9}$ As examples, see Bikker and Haaf (2002), Coccorese (2004), and Casu and Girardone (2009).
} 
entries in the various local markets would have been inevitable. Finding entry deterrence too costly, they opted for accommodation and concentrated on maximizing their own profits.

Since prices are supposed strategic complements for banks (Bulow et al., 1985), an investment in capacity (branches) from bank $i$ would have the same effect on both its own and competitors' profits. Our empirical evidence that $\partial M C_{j} / \partial B R_{i}>0$ and $\partial p_{i} / \partial B R_{i}>0^{10}$ means that the investment $B R_{i}$ increases both marginal cost and price of bank $i$. In turn, a higher price for bank $i$ forces the other banks to charge a higher price as well (because of strategic complementarity of prices), which helps bank is profits. As a result, the optimal choice for bank $i$ is to overinvest (keeping a 'fat cat' profile) so as not to look aggressive and trigger an aggressive reaction by rivals. We may also say that a bank competing in prices in an accommodation framework ought to look inoffensive in order not to induce its rivals to cut their prices. To pursue this aim, it needs to take actions that commit it to charge a high price, i.e. investments that increase production costs, here corresponding to the opening of new branches (Tirole, 1988, pp. 326-328). This 'fat cat' strategy consists in an overinvestment in capacity in the first stage that accommodates entry by committing the incumbent to play less aggressively in the (post-entry) second stage (Fudenberg and Tirole, 1984, p. 365).

There is another important result deriving from our estimations. As formerly discussed, since we are dealing with a 'fat cat' game (as $\partial M C_{j} / \partial B R_{i}>0$ ) where the conjectural variation parameter $\lambda$ is negative, employing a one-stage framework that does not include the capacity choice would produce an upward bias in the estimate of market conduct (i.e. its absolute value would be lower). Strictly speaking, ignoring the strategic linkages between competition in capacity and prices makes the competition look weaker than it actually is.

To check empirically this result, and also quantify the magnitude and direction of the bias, we have estimated another group of systems where the endogeneity of branching decisions has been ignored. Particularly, we have considered a one-stage simultaneous model where the equations of both the short-run marginal cost and the marginal cost of capital have been replaced by the following marginal cost function:

$$
\frac{p_{i t}-\left(b_{0}+b_{1} r_{i t}+b_{2} \omega_{1 i t}+b_{3} \omega_{2 i t}+b_{4} E \text { MPLBR }_{i t}+b_{5} \text { PROVPRES }_{i t}+b_{6} t\right)}{p_{i t}}=-\frac{1}{a_{1}+\lambda a_{2} \frac{p_{i}}{p_{j}}}+\varphi_{i t}
$$

In (5c), the capacity variable $B R_{i t}$ has been replaced by the price of capital $r_{i t}$. In this way, we come back to a well-specified marginal cost function, and there is no difference between short-run and long-run costs anymore (Roller and Sickles, 2000, p. 858).

The new models are composed by Equations (1a) and (5c), and correspond to the customary structural models that are often employed when studying industries with market power.

Table 4 reports the estimation results. The sign and significance of the coefficients of the demand equation do not change. It is worth only noting that the absolute values of both $a_{1}$ and $a_{2}$ are slightly higher than before. Regarding the behavioural index, we find a strong confirmation to our conjecture about the direction of bias (see Proposition 1). Particularly, the conjectural derivative $\lambda$ is always higher in the one-stage estimation than in the two-stage framework: as an example, for the whole sample it increases from -0.1667 to -0.0178 (still statistically significant at the $1 \%$ level). This means that, as $\lambda<0$, in our 'fat cat' game the

\footnotetext{
${ }^{10}$ Recall that $\operatorname{sign}\left\{\partial p_{i} / \partial B R_{i}\right\}=\operatorname{sign}\left\{\partial p_{j} / \partial B R_{i}\right\}$ : see Section 3.
} 
two-stage framework significantly adjusts downward the value of the market conduct parameter and the measurement of the market power of incumbent firms.

In order that the results of our two-stage model be economically meaningful, we need that the second-order conditions of stages 2 and 1 are satisfied. As shown in the Appendix, for stage 2 it must be $\Delta_{i}<0$, i.e. $\frac{\partial q_{i}}{\partial p_{i}}+\frac{\partial q_{i}}{\partial p_{j}} \lambda<0$. This always holds, given that - according to the functional form of demand here adopted as well as to the estimated parameters - we have $\frac{\partial q_{i}}{\partial p_{i}}=a_{1} \frac{q_{i}}{p_{i}}<0, \frac{\partial q_{i}}{\partial p_{j}}=a_{2} \frac{q_{i}}{p_{j}}>0$, and $\lambda<0$.

With regard to stage 1 , since $b_{1}=\partial M C_{i} / \partial B R_{i}>0$, we need that $\partial p_{i} / \partial B R_{i}-\partial M C_{i} / \partial B R_{i}<0$. This condition is also satisfied at the sample means for all specifications: for example, in the model concerning the whole sample of banks we have that $\frac{\partial p_{i}}{\partial B R_{i}}=\frac{\partial M C_{i}}{\partial B R_{i}} \Delta_{i} \frac{A}{A^{2}-B^{2}}=0.00027$, while $\frac{\partial M C_{i}}{\partial B R_{i}}=b_{1}=0.00039$, so that the difference between them amounts to -0.00012 (for the other models, the corresponding differences are $-0.00013,-0.00002$ and -0.00001$)$.

Another restriction that must be met is the first-order condition of stage 1, namely (9). In our framework, it is $\left(p_{i}-M C_{i}\right) \frac{\partial q_{i}}{\partial p_{j}} \frac{\partial p_{j}}{\partial B R_{i}}>0$, because each term of this strategic effect on $\pi_{i}$ of an investment in capacity (i.e. $p_{i}-M C_{i}, \frac{\partial q_{i}}{\partial p_{j}}=a_{2} \frac{q_{i}}{p_{j}}$ and $\frac{\partial p_{j}}{\partial B R_{i}}=\alpha$ ) is greater than zero. A positive strategic effect means that investing in branches from bank $i$ causes an increase in the rivals' price (the 'fat cat' effect), and this generates an increase in bank is loans as well as in the gap between the price and marginal costs. So we need that $-\frac{\partial C_{i}^{S R}}{\partial B R_{i}}-r_{i}<0$, indicating that the direct effect of investing in capacity (branches) must be negative: this means that setting up a branch is unprofitable by itself (i.e. costly) for bank $i$, and that the incentive to invest in capacity is entirely attributable to the strategic effect. According to our empirical results, this direct effect is always negative at the sample means (and amounts to 87.45 in the reference sample). 


\section{Conclusions}

This paper has focused on estimating the conduct of Italian banks in presence of endogenous branching decisions, which are among the most studied measures of non-price competition in banking. Methodologically, this has been done by adding to the typical twoequation model (a demand function plus a first-order condition in the loan market) a third equation that records how capacity decisions (regarding de novo branches) affect short-run marginal costs.

The Italian banking industry represents an ideal testing ground for our model. In the recent years there have been both a deregulation wave and a sharp increase in the number of branches, while at the same time the number of banks has reduced. Hence, an endogenous treatment of branch decisions appears appropriate.

We have estimate this model using data on a group of (large-size and medium-size) Italian banks for the years 1995-2009. Our results point toward a rejection of the simple one-stage specification, thus confirming the role of non-price strategic behaviour as a key attribute of firms' conduct that stems from their interdependence in an imperfectly competitive context. Moreover, we show that the market conduct of banks in the two-stage model is significantly more competitive than a Bertrand-Nash game as well as than that coming from a one-stage formulation. Finally, the strategic behaviour of banks toward branches is such that, in the Fudenberg and Tirole (1984)'s terminology, they behave as 'fat cats', overinvesting in their office network (which causes an increase in marginal costs) so as to keep prices high and, as a consequence, accommodate entry. 


\section{Appendix - Second-order conditions}

\section{Stage 2}

From (4) we can calculate the second derivative with respect to $p_{i}$ :

$$
\frac{\partial^{2} \pi_{i}}{\partial p_{i}^{2}}=\left(\frac{\partial q_{i}}{\partial p_{i}}+\frac{\partial q_{i}}{\partial p_{j}} \frac{\partial p_{j}}{\partial p_{i}}\right)\left[2-\frac{\partial M C_{i}}{\partial q_{i}}\left(\frac{\partial q_{i}}{\partial p_{i}}+\frac{\partial q_{i}}{\partial p_{j}} \frac{\partial p_{j}}{\partial p_{i}}\right)\right]=\Delta_{i}\left(2-\frac{\partial M C_{i}}{\partial q_{i}} \Delta_{i}\right)
$$

Since our two-stage marginal cost function (12) does not depend on the variable $q_{i}$, it is $\partial M C_{i} / \partial q_{i}=0$. So the above second-order condition holds whenever $\Delta_{i}<0$.

\section{Stage 1}

Starting from (9), and assuming our two-stage functional specification (13) of $\partial C_{i}^{S R} / \partial B R_{i}$, which does not depend on $B R_{i}$, we can write the second derivative with respect to $B R_{i}$ as follows:

$$
\frac{\partial^{2} \pi_{i}}{\partial B R_{i}^{2}}=\left(\frac{\partial p_{i}}{\partial B R_{i}}-\frac{\partial M C_{i}}{\partial B R_{i}}\right) \frac{\partial q_{i}}{\partial p_{j}} \frac{\partial p_{j}}{\partial B R_{i}}
$$

Recall that $\partial q_{i} / \partial p_{j}>0$, and also that $\operatorname{sign}\left\{\partial M C_{i} / \partial B R_{i}\right\}=\operatorname{sign}\left\{\partial p_{i} / \partial B R_{i}\right\}=\operatorname{sign}\left\{\partial p_{j} / \partial B R_{i}\right\}$. This means that: a) when $\partial M C_{i} / \partial B R_{i}<0$, the above second-order condition is satisfied for $\partial p_{i} / \partial B R_{i}-\partial M C_{i} / \partial B R_{i}>0$; b) when $\partial M C_{i} / \partial B R_{i}>0$, we need that $\partial p_{i} / \partial B R_{i}-\partial M C_{i} / \partial B R_{i}<0$. 


\section{References}

Alexander, D.L., 1988. The oligopoly solution tested. Economics Letters 28, 361-364.

Angelini, P., Cetorelli, N., 2003. The effects of regulatory reform on competition in the banking industry. Journal of Money Credit and Banking 35, 663-684.

Appelbaum, E., 1979. Testing price taking behaviour. Journal of Econometrics 9, 283-294.

Appelbaum, E., 1982. The estimation of the degree of oligopoly. Journal of Econometrics 19, 287-299.

Barros, P., 1999. Multimarket competition in banking with an example from the case of Portuguese market. International Journal of Industrial Organization 17, 335-352.

Berg, S.A., Kim, M., 1994. Oligopolistic interdependence and the structure of production in banking: An empirical evaluation. Journal of Money, Credit, and Banking 26, 309-322.

Bikker, J.A., Haaf, K., 2002. Competition, concentration and their relationships: An empirical analysis of the banking industry. Journal of Banking and Finance 26, 2191-2214.

Bofondi, M., Gobbi, G., 2006. Informational barriers to entry into credit markets. Review of Finance 10, 39-67.

Bresnahan, T.F., 1982. The oligopoly solution concept is identified. Economics Letters 10, 87-92.

Bresnahan, T.F., 1989. Empirical studies of industries with market power. In: Schmalensee, R., Willig, R.D. (Eds.), Handbook of Industrial Organisation, Vol. 2. North-Holland: Amsterdam, 1012-1057.

Bulow, J.I., Geanakoplos, J.D., Klemperer, P.D., 1985. Multimarket oligopoly: strategic substitutes and complements. Journal of Political Economy 93, 488-511.

Calcagnini, G., De Bonis, R., Hester, D.D., 2002. Determinants of bank branch expansion in Italy. In: Calcagnini, G., Hester, D.D. (Eds.), Banking Changes in the European Monetary Union. An Italian Perspective. Roma: Carocci, 157-177.

Canhoto, A., 2004. Portuguese banking: A structural model of competition in the deposits market. Review of Financial Economics 13, 41-63.

Carbo Valverde, S., Ferndandez de Guevara, J., Humphrey, D., Maudos, J., 2009. Estimating the intensity of price and non-price competition in banking. Banks and Bank Systems 4(2), 4-19.

Casu, B., Girardone, C., 2009. Competition issues in European banking. Journal of Financial Regulation and Compliance 17, 119-133.

Cerasi, V., Chizzolini, B., Ivaldi, M., 2000. L'apertura di sportelli e la concorrenza nel settore bancario italiano. In: Polo, M. (Ed.), Industria bancaria e concorrenza. Bologna: II Mulino, 499-522. 
Cerasi, V., Chizzolini, B., Ivaldi, M., 2002. Branching and Competition in the European Banking Industry. Applied Economics 34, 2213-2225.

Coccorese, P., 1998. The degree of competition in the Italian banking industry. Economic Notes 3, 355-370.

Coccorese, P., 2004. Banking competition and macroeconomic conditions: a disaggregate analysis. Journal of International Financial Markets, Institutions and Money 14, 203-219.

Coccorese, P., 2005. Competition in markets with dominant firms: a note on the evidence from the Italian banking industry. Journal of Banking and Finance 29, 1083-1093.

Coccorese, P., 2008. Bank competition and regional differences. Economics Letters 101, 13-16.

Coccorese, P., 2009. Market power in local banking monopolies. Journal of Banking and Finance 33, 1196-1210.

Corvoisier, S., Gropp, R., 2002. Bank concentration and retail interest rates. Journal of Banking and Finance 26, 2155-2189.

Corvoisier, S., Gropp, R., 2007. Contestability, technology and banking. ZEW Discussion Paper, n. 09-007.

De Bonis, R., Farabullini, F., Fornari, F., 1998. La localizzazione territoriale degli sportelli bancari e le determinanti delle aperture. Rivista Economica del Mezzogiorno 12(1), 69104.

Dewit, G., Leahy, D., 2009. Oligopsonistic cats and dogs. Review of Industrial Organization 35, 257-274.

Dick, A., 2007. Market size, service quality, and competition in banking. Journal of Money, Credit and Banking 39, 49-81.

Dick, A., 2008. Demand estimation and consumer welfare in the banking industry. Journal of Banking and Finance 32, 1661-1676.

ECB, 2010. EU banking structures, September. Frankfurt am Main.

Farrell, J., Shapiro, C., 1990. Horizontal mergers: an equilibrium analysis. American Economic Review 81, 107-125.

Fershtman, C., Gandal, N., 1994. Disadvantages semicollusion. International Journal of Industrial Organization 12, 141-154.

Fudenberg, D., Tirole, J., 1984. The fat-cat effect, the puppy-dog ploy and the lean and hungry look. American Economic Review 74, Papers and Proceedings, 361-366.

Gual, L., 1999. Deregulation, integration and market structure in European banking, CEPR Discussion Paper, n. 2288.

Iwata, G., 1974. Measurement of conjectural variations in oligopoly. Econometrica 42, 947-966.

Jayaratne, J., Strahan, P.E., 1996. The finance-growth nexus: evidence from bank branch deregulation. Quarterly Journal of Economics 111, 639-670. 
Kim, M., Vale, B., 2001. Non-price strategic behavior: the case of bank branches. International Journal of Industrial Organization 19, 1583-1602.

Lau, L., 1982. On identifying the degree of competitiveness from industry price and output data. Economics Letters 10, 93-99.

Ma, T.C., 2005. Strategic investment and excess capacity: a study of the Taiwanese flour industry. Journal of Applied Economics 13, 153-170.

Martin, S., 1993. Advanced Industrial Economics. Cambridge: Blackwell.

Maudos, J., Fernandez de Guevara, J., 2007. The cost of market power in banking: social welfare loss vs. cost inefficiency. Journal of Banking and Finance 31, 2103-2125.

Neven, D., Roller, L.H., 1999. An aggregate structural model of competition in the European banking industry. International Journal of Industrial Organization 17, 10591074.

Neven, D.J., Roller, L.H., Zhan, Z., 2006. Endogenous costs and price-cost margins: an application to the European airline industry. Journal of Industrial Economics 54, 351-368.

Pinho, P., 2000. The impact of deregulation on price and non-price competition in the Portuguese deposits market. Journal of Banking and Finance 24, 1515-1533.

Roberts, M., 1984. Testing oligopolistic behaviour. International Journal of Industrial Organization 2, 367-383.

Roller, L.H., Sickles R.C., 2000. Capacity and product market competition: measuring market power in a 'puppy-dog' industry. International Journal of Industrial Organization $18,845-865$.

Shaffer, S., 1989. Competition in the U.S. banking industry. Economics Letters 29, 321-323.

Shaffer, S., 1993. A test of competition in Canadian banking. Journal of Money, Credit, and Banking 25, 49-61.

Shaffer, S., 2004. Patterns of competition in banking. Journal of Economics and Business 56, 287-313.

Shaffer, S., DiSalvo, J., 1994. Conduct in a banking duopoly. Journal of Banking and Finance 18, 1063-1082.

Sutton, J., 1991. Sunk Cost and Market Structure: Price Competition, Advertising, and the Evolution of Concentration. Cambridge: MIT Press.

Tirole, J., 1988. The Theory of Industrial Organization. Cambridge: MIT Press.

Toolsema, L.A., 2002. Competition in the Dutch consumer credit market. Journal of Banking and Finance 26, 2215-2229.

Uchida, H., Tsutsui, Y., 2005. Has competition in the Japanese banking sector improved?. Journal of Banking and Finance 29, 419-439.

van Leuvensteijn, M., Bikker, J.A., van Rixtel, A., Sorensen, C.K., 2007. A new approach to measuring competition in the loan markets of the Euro area. ECB Working Paper, $\mathrm{n}$. 768. 


\section{Tables}

\begin{tabular}{|c|c|c|c|c|c|c|c|c|}
\hline Year & Branches & Banks & $\begin{array}{l}\text { Branches } \\
\text { per bank }\end{array}$ & $\begin{array}{c}\text { Branch } \\
\text { variation } \\
(\%)\end{array}$ & $\begin{array}{l}\text { Branches per } \\
\text { municipality }\end{array}$ & $\begin{array}{c}\text { Municipalities } \\
\text { with at least } \\
\text { one branch } \\
(\%)\end{array}$ & $\begin{array}{l}\text { Branches } \\
\text { per million } \\
\text { inhabitants }\end{array}$ & $\begin{array}{c}\text { Loans to } \\
\text { GDP ratio } \\
\text { (\%) }\end{array}$ \\
\hline 1990 & 16596 & 1064 & 15.6 & 6.6 & 2 & 62.9 & 292.6 & 57.8 \\
\hline 1991 & 18396 & 1043 & 17.6 & 10.8 & 2.3 & 64.6 & 324.1 & 60.6 \\
\hline 1992 & 19822 & 1025 & 19.3 & 7.8 & 2.4 & 66.7 & 349.0 & 66.3 \\
\hline 1993 & 22004 & 992 & 21.5 & 7.4 & 2.6 & 67.6 & 387.2 & 67.2 \\
\hline 1994 & 23000 & 965 & 23.3 & 5.4 & 2.8 & 69 & 404.6 & 64 \\
\hline 1995 & 24040 & 976 & 24 & 4.3 & 2.9 & 69.6 & 422.9 & 65.3 \\
\hline 1996 & 24406 & 938 & 26 & 4.2 & 3 & 70.1 & 429.2 & 64.3 \\
\hline 1997 & 25250 & 935 & 27 & 3.5 & 3.1 & 70.4 & 443.8 & 65.1 \\
\hline 1998 & 26258 & 922 & 28.5 & 4 & 3.2 & 73.1 & 461.4 & 68.1 \\
\hline 1999 & 27134 & 875 & 31 & 3.3 & 3.4 & 73.4 & 476.7 & 72.1 \\
\hline 2000 & 28177 & 841 & 33.5 & 3.9 & 3.5 & 73.3 & 494.8 & 76.5 \\
\hline 2001 & 29270 & 830 & 35.3 & 3.8 & 3.6 & 73.4 & 513.7 & 77.8 \\
\hline 2002 & 29926 & 814 & 36.8 & 2.2 & 3.7 & 73.3 & 523.6 & 79.3 \\
\hline 2003 & 30480 & 789 & 38.7 & 1.8 & 3.8 & 73.2 & 529.1 & 81.7 \\
\hline 2004 & 30944 & 778 & 39.8 & 1.5 & 3.8 & 73.1 & 531.9 & 82.7 \\
\hline 2005 & 31501 & 783 & 40.2 & 1.8 & 3.9 & 73.1 & 537.5 & 86.7 \\
\hline 2006 & 32338 & 793 & 40.8 & 2.7 & 4 & 73.1 & 548.6 & 92.3 \\
\hline 2007 & 33229 & 806 & 41.2 & 2.8 & 4.1 & 73 & 559.6 & 97.1 \\
\hline 2008 & 34146 & 799 & 42.7 & 2.8 & 4.2 & 73.1 & 570.7 & 99.6 \\
\hline 2009 & 34036 & 788 & 43.2 & -0.3 & 4.2 & 73.1 & 564.8 & 102.8 \\
\hline
\end{tabular}

Table 1 - Structural changes in the Italian banking industry (1990-2009) 


\begin{tabular}{lccccc} 
Variable & Mean & Std. Dev. & Minimum & Maximum & Median \\
\hline$q$ & 7140.5 & 14349.5 & 191.6 & 168307.8 & 2203.4 \\
$p_{i}$ & 9.67 & 5.14 & 1.68 & 32.71 & 7.76 \\
$B R$ & 226.36 & 325.77 & 14 & 3142 & 98 \\
$p_{j}$ & 7.64 & 2.41 & 4.66 & 15.76 & 6.83 \\
GDP & 102954.2 & 62236.4 & 19922.1 & 267467.7 & 98091.5 \\
BRSHARE & 0.77 & 1.08 & 0.06 & 9.46 & 0.32 \\
$\omega_{1}$ & 4.31 & 2.39 & 0.53 & 17.27 & 3.60 \\
$\omega_{2}$ & 56.95 & 7.22 & 16.27 & 99.10 & 56.49 \\
$r$ & 421.12 & 166.91 & 153.64 & 2413.10 & 387.92 \\
EMPLBR & 10.85 & 3.63 & 5.67 & 37.61 & 10.09 \\
PROVPRES & 18.70 & 24.12 & 0.93 & 100 & 7.77 \\
BRFQLOAN & 51.96 & 32.35 & 0 & 100 & 60.82 \\
BRPOP & 3.91 & 5.61 & 0.25 & 53.14 & 1.69
\end{tabular}

Table 2 - Sample descriptive statistics (1995-2009)

Note:

$q=$ total customer loans (millions of 2000 euro)

$p_{i}=$ interest revenue $/$ total customer loans (percentage)

$B R=$ number of branches (units)

$p_{j}=$ interest revenue $/$ total customer loans (percentage)

$G D P=$ weighted Gross Domestic Product (millions of 2000 euro)

$B R S H A R E=$ number of branches of the bank / total number of branches in the country (percentage)

$\omega_{1}=$ interest expenses $/$ total deposits (percentage)

$\omega_{2}=$ labour costs / number of employees (thousands of 2000 euro)

$r=$ other operating costs / number of branches (thousands of 2000 euro)

$E M P L B R=$ employees per branch (units)

$P R O V P R E S$ = share of provinces where the bank owns at least one branch (percentage)

$B R F Q L O A N=$ share of branches in local markets with loans over the first quartile (percentage)

$B R P O P=$ branches per million of inhabitants (units)

Number of banks in the sample: 117

Number of observations: 1417 
Whole sample

North

Center \& South

Banks operating in more than 10 regions

\begin{tabular}{|c|c|c|c|c|c|c|c|c|c|c|c|c|c|}
\hline \multicolumn{2}{|l|}{ Variable } & Coefficient & $t$-value & & Coefficient & $t$-value & & Coefficient & $t$-value & & Coefficient & $t$-value & \\
\hline & & \multicolumn{12}{|c|}{ Demand equation } \\
\hline $\ln p_{i}$ & $a_{1}$ & -0.75324 & -26.20 & $* * *$ & -0.61511 & -17.75 & $* * *$ & -0.81430 & -14.29 & $\star \star *$ & -0.58733 & -8.89 & $* * *$ \\
\hline $\ln p_{j}$ & $a_{2}$ & 0.79316 & 19.65 & $\star * *$ & 0.61096 & 13.18 & $\star \star *$ & 0.96903 & 12.16 & $* * *$ & 0.87805 & 8.56 & *** \\
\hline $\ln G D P_{i}$ & $a_{3}$ & 0.51432 & 8.52 & $\star * *$ & 0.54436 & 7.05 & $\star \star *$ & 0.76424 & 60.06 & $\star \star \star *$ & 0.69649 & 35.40 & $* * *$ \\
\hline $\ln B R S H A R E_{i}$ & $a_{4}$ & 0.89906 & 29.45 & $* * *$ & 0.81835 & 21.29 & $\star * *$ & 0.67934 & 15.26 & $\star \star *$ & 0.91908 & 13.17 & $* * *$ \\
\hline \multirow[t]{2}{*}{$t$} & $a_{5}$ & 0.01836 & 8.24 & $\star * *$ & 0.02978 & 10.59 & $\star * *$ & 0.01451 & 3.84 & $\star \star *$ & 0.01762 & 2.60 & *** \\
\hline & \multicolumn{13}{|c|}{ Short-run marginal cost (stage 2) } \\
\hline Constant & $b_{0}$ & -0.03098 & -0.12 & & -0.57681 & -1.73 & * & -0.86659 & -1.47 & & 0.99213 & 1.25 & \\
\hline$B R_{i}$ & $b_{1}$ & 0.00039 & 4.17 & $* * *$ & 0.00035 & 2.95 & $* * *$ & 0.00014 & 0.30 & & 0.00010 & 0.55 & \\
\hline$\omega_{1 t}$ & $b_{2}$ & 0.00862 & 0.39 & & -0.08391 & -2.58 & $\star \star \star$ & 0.02679 & 0.55 & & -0.06355 & -0.69 & \\
\hline$\omega_{2 l}$ & $b_{3}$ & -0.00355 & -1.10 & & -0.00416 & -0.88 & & 0.00120 & 0.18 & & -0.01186 & -1.44 & \\
\hline$E M P L B R_{i}$ & $b_{4}$ & -0.02391 & -2.41 & ** & -0.01229 & -0.80 & & 0.03102 & 1.43 & & -0.07940 & -3.40 & $* * *$ \\
\hline PROVPRES $_{i}$ & $b_{5}$ & -0.00334 & -2.16 & $* *$ & -0.00490 & -2.47 & ** & -0.00407 & -0.71 & & -0.00219 & -0.45 & \\
\hline \multirow[t]{2}{*}{$t$} & $b_{6}$ & -0.02861 & -2.73 & $* * *$ & -0.02549 & -1.82 & * & -0.00988 & -0.41 & & -0.03775 & -0.99 & \\
\hline & \multicolumn{13}{|c|}{ Marginal cost of capital (stage 1) } \\
\hline Constant & $c_{0}$ & -388.13240 & -30.13 & $* * *$ & 389.55595 & -20.62 & *** & -395.09975 & -23.78 & *** & -510.32980 & -3.85 & *** \\
\hline$q_{i}$ & $c_{1}$ & 0.01043 & 4.85 & $* * *$ & 0.01032 & 3.18 & $\star * *$ & 0.00303 & 1.24 & & 0.01790 & 4.37 & *** \\
\hline$B R F Q L O A N_{i}$ & $c_{2}$ & -0.92760 & -7.32 & $* * *$ & -0.82281 & -4.71 & *** & -1.45437 & -6.50 & $* * *$ & 1.10102 & 0.61 & \\
\hline$B R P O P_{i}$ & $c_{3}$ & 13.60211 & 8.53 & $* * *$ & 10.81521 & 5.56 & $* * *$ & 23.95357 & 8.19 & $* \star *$ & 21.43891 & 6.05 & $* * *$ \\
\hline \multirow[t]{2}{*}{$t$} & $C_{4}$ & 2.10316 & 2.03 & ** & 1.95626 & 1.35 & & 3.08207 & 2.26 & ** & -19.87231 & -3.81 & $* * *$ \\
\hline & \multicolumn{13}{|c|}{ Parameters } \\
\hline $\begin{array}{l}\text { Conjectural } \\
\text { derivative }\end{array}$ & $\lambda$ & -0.16662 & -6.57 & $* * *$ & -0.28877 & -6.39 & $\star \star *$ & -0.10827 & -2.82 & $* \star *$ & -0.23584 & -4.11 & *** \\
\hline$\partial p_{j} / \partial B R_{i}$ & $\alpha$ & 0.01916 & 7.44 & $* * *$ & 0.02039 & 4.63 & $* * *$ & 0.01378 & 5.05 & $\star * *$ & 0.02045 & 5.05 & $* * *$ \\
\hline N. of observat & ons & 1417 & & & 862 & & & 555 & & & 226 & & \\
\hline N. of banks & & 117 & & & 74 & & & 43 & & & 25 & & \\
\hline
\end{tabular}

Table 3 - Two-stage simultaneous equation model: estimation results

Note:

The system has been estimated with three-stage least squares.

The instruments used are: levels and logs of first-lagged and second-lagged $q_{i}, p_{i}, p_{i}$ and $B R_{i}$; levels and logs of $G P_{i}, B R S H A R E_{i}, \omega_{1}, \omega_{2}, r_{i}, E M P L B R_{i}, P R O V P R E S_{i}, B R F Q L O A N_{i}, B R P O P_{i}$ and total assets; time trend; bank dummies.

Significance for the parameter estimates: ${ }^{* *}=1 \%$ level; ${ }^{* *}=5 \%$ level; ${ }^{*}=10 \%$ level.

In the demand equation a set of dummy variables capturing bank effects is also added (coefficient estimates are not reported). 


\section{Whole sample}

North

Center \& South

Banks operating in more than 10 regions

\begin{tabular}{|c|c|c|c|c|c|c|c|c|c|c|c|c|c|}
\hline \multicolumn{2}{|l|}{ Variable } & Coefficient & $t$-value & & Coefficient & $t$-value & & Coefficient & $t$-value & & Coefficient & $t$-value & \\
\hline & \multicolumn{13}{|c|}{ Demand equation } \\
\hline $\ln p_{i}$ & $a_{1}$ & -0.95595 & -85.36 & $\star * *$ & -0.86308 & -44.73 & $* * *$ & -0.98839 & -84.68 & $\star * *$ & -0.81762 & -23.21 & $* * *$ \\
\hline $\ln p_{j}$ & $a_{2}$ & 1.01624 & 35.66 & $* * *$ & 0.87928 & 25.61 & $* * *$ & 1.18442 & 23.11 & $\star * *$ & 1.08306 & 12.78 & $* * *$ \\
\hline $\ln G D P_{i}$ & $a_{3}$ & 0.51683 & 8.36 & $\star * *$ & 0.58224 & 7.47 & $* * *$ & 0.77530 & 61.62 & $\star * *$ & 0.71269 & 39.66 & $* * *$ \\
\hline $\ln B R S H A R E_{i}$ & $a_{4}$ & 0.89144 & 28.53 & $\star * *$ & 0.82955 & 21.31 & $* * *$ & 0.56844 & 12.81 & $\star * *$ & 0.92172 & 14.30 & $* * *$ \\
\hline \multirow[t]{2}{*}{$t$} & $a_{5}$ & 0.00984 & 4.97 & $\star * *$ & 0.01823 & 7.22 & $* * *$ & 0.00989 & 3.19 & $\star * *$ & 0.00846 & 1.44 & \\
\hline & \multicolumn{13}{|c|}{ Marginal cost } \\
\hline Constant & $b_{0}$ & -0.03168 & -0.44 & & -0.21345 & -1.72 & * & -0.00844 & -0.11 & & -0.50050 & -1.76 & * \\
\hline$B R_{i}$ & $b_{1}$ & 0.00001 & -0.13 & & 0.00010 & 0.83 & & -0.00004 & -0.76 & & -0.00016 & -0.90 & \\
\hline$\omega_{1 \imath}$ & $b_{2}$ & -0.02238 & -3.62 & $\star * *$ & -0.06549 & -5.51 & $* * *$ & -0.00708 & -1.21 & $\star * *$ & -0.13018 & -3.86 & $* * *$ \\
\hline$\omega_{2 l}$ & $b_{3}$ & -0.00099 & -1.02 & & -0.00238 & -1.38 & & -0.00012 & -0.13 & & -0.00441 & -1.49 & \\
\hline$E M P L B R_{i}$ & $b_{4}$ & -0.00053 & -0.16 & & -0.00209 & -0.30 & & 0.00012 & 0.04 & & 0.01226 & 1.27 & \\
\hline PROVPRES $_{i}$ & $b_{5}$ & 0.00025 & 0.76 & & -0.00033 & -0.58 & & 0.00022 & 0.67 & & -0.01529 & -0.23 & \\
\hline \multirow[t]{2}{*}{$t$} & $b_{6}$ & -0.00020 & -0.07 & & 0.00122 & 0.24 & & -0.00001 & 0.00 & & 0.01529 & 1.17 & \\
\hline & \multicolumn{13}{|c|}{ Behavioural parameter } \\
\hline $\begin{array}{l}\text { Conjectural } \\
\text { derivative }\end{array}$ & $\lambda$ & -0.01777 & -3.28 & $\star * *$ & -0.06158 & -5.56 & $* * *$ & -0.00382 & -0.80 & & -0.04890 & -3.84 & $* * *$ \\
\hline \multicolumn{2}{|c|}{ N. of observations } & 1417 & & & 862 & & & 555 & & & 226 & & \\
\hline \multicolumn{2}{|l|}{ N. of banks } & 117 & & & 74 & & & 43 & & & 25 & & \\
\hline
\end{tabular}

Table 4 - One-stage simultaneous equation model: estimation results

Note:

The system has been estimated with three-stage least squares.

The instruments used are: levels and logs of first-lagged and second-lagged $q_{i}, p_{i}, p_{j}$ and $B R_{i}$; levels and logs of $G D P_{i}, B R S H A R E_{i}, \omega_{1}, \omega_{2} i, r_{i}, E M P L B R i, P R O V P R E S_{i}, B R F Q L O A N_{i}, B R P O P_{i}$ and total assets; time trend; bank dummies.

Significance for the parameter estimates: ${ }^{* * *}=1 \%$ level; ${ }^{* *}=5 \%$ level; ${ }^{*}=10 \%$ level.

In the demand equation a set of dummy variables capturing bank effects is also added (coefficient estimates are not reported). 


\section{CELPE's Discussion Papers}

2010, 117 Sergio DESTEFANIS, Giovanni PICA

The Wage Curve an Italian Perspective

2010, 116 Adalgiso AMENDOLA, Joshy EASAW, Antonio SAVOIA

Inequality in Developing Economies: The Role of Institutional Development

2010115 Gianluigi COPPOLA

Health, Lifestyle and Growth

2010114 Teresa AMODIO

Methods of Analysis of Local Tourist Systems

2009113 Fernanda MAZZOTTA

The Effect of Parental Background on Youth Duration of Unemployment

2009112 Matteo FRAGETTA

Identification in Structural Vector Autoregressions Through Graphical Modelling and Monetary Policy: A Cross-Country Analysis

2009111 Bruna BRUNO, Damiano FIORILLO

Why without Pay? The Intrinsic Motivation between Investment and Consumption in Unpaid Labour Supply

2009110 Maria Rosaria GAROFALO, Annamaria NESE

Social Preferences and the Third Sector: Looking for a Microeconomic Foundation of the Local Development Path

2008109 Giorgia IOVINO

Gis, ricerca geografica e pianificazione urbanistica: un'applicazione sul centro storico di Benevento

2008108 Bruna BRUNO

La donna flessibile e il lavoro opportuno

2008107 Damiano FIORILLO

Offerta di Attività Gratuita in Italia: una analisi micro-econometrica

2007, 106 Shane Niall O'HIGGINS, Marcello D'AMATO, Floro Ernesto CAROLEO, Adriana BARONE

Gone for Good? Determinants of School Dropout in Southern Italy

2007, 105 Ugo COLOMBINO, Annamaria NESE

Preference Heterogeneity in Relation to Museum Services

2007, 104 Giuseppe CELI, Mario SPORTELLI

Harrod's Dynamics and the Kaldor-Thirlwall Export-led Growth

2007, 103 Francesca BETTIO, Fernanda MAZZOTTA, Giovanni SOLINAS

Costs and prospects for home based Long Term Care in Northern Italy: the Galca survey 
2007, 102 Lisa CROSATO, Sergio DESTEFANIS, Piero GANUGI

Technology and Firm Size Distribution: Evidence from Italian Manufacturing

2007, 101 Guglielmo Maria CAPORALE, Alexandros KONTONIKAS

The Euro and Inflation Uncertainty in the european Monetary Union

2006, 100 Francesco Paolo VOLPE

Principio democratico e giustizia nell'amministrazione

2006, 99 Niall O'HIGGINS

Still With Us After All of These Years: Trends in Youth Labour Market Entry, HomeLeaving And Human Capital Accumulation in Italy 1993-2003

2005, 98 Floro Ernesto CAROLEO, Gianluigi COPPOLA

The Impact of the Institutions on Regional Unemployment Disparities

2005, 97 Carlo ALTAVILLA, Antonio GAROFALO, Concetto Paolo VINCI

Is the Discouraged Worker Effect Time-Varying?

2005, 96 F. BUSATO, B. CHIARINI, P. DE ANGELIS, E. MARZANO

Capital Subsidies and Underground Production

2005, 95 Lucio Valerio SPAGNOLO, Mario CERRATO

No euro please, We're British!

2005, 94 Roberto BASILE, Mauro COSTANTINI, Sergio DESTEFANIS

Unit root and cointegration tests for cross-sectionally correlated panels. Estimating regional production functions

2005, 93 Sergio DESTEFANIS, Raquel FONSECA

Matching Efficiency and Labour Market Reform in Italy. A Macroeconometric Assessment

2005, 92 Cesare IMBRIANI, Antonio LOPES

Banking System Efficiency and the Dualistic Development of the Italian Economy in the Nineties

2005, 91 Carlo ALTAVILLA, Antonio GAROFALO, Concetto Paolo VINCI

Designing the Optimal Lenght of Working Time

2005, 90 Marco MANACORDA, Barbara PETRONGOLO

Regional Mismatch and Unemployment: Theory and Evidence from Italy, 1977-1998

2004, 89 Roberta TROISI

Teoria dellimpresa e responsabilità parapenale: le implicazioni organizzativo-gestionali

2004, 88 Roberta TROISI

Enti non profit: tipologie ed opzioni organizzative

2004, 87 Lavinia PARISI

La povertà: una rassegna sul confronto tra due approcci. Capability vs. Unidimensionalità 
2004, 86 Giuseppe CELI

Quality Differentiation, Vertical Disintegration and the Labour Market Effetcs of Intra-Industry Trade

2004, 85 Niall O'HIGGINS

Recent Trends in Youth Labour Martkets and Employment Policy in Europe and Centra Asia

2004, 84 Carlo ALTAVILLA, Floro Ernesto CAROLEO

Evaluating Asimmetries in Active Labour Policies: The Case of Italy

2004, 83 Floro Ernesto CAROLEO, Francesco PASTORE

La disoccupazione giovanile in Italia. La riforma dei sistemi d'istruzione e di formazione professionale come alternativa alla flessibilità numerica per accrescere l'occupabilità

2004, 82 Francesco PASTORE, Izabela MARCINKOWSKA

The Gender Wage Gap among Young People in Italy

2004, 81 Elisabetta MARZANO

Dual Labour Market Theories And Irregular Jobs: IsThere a Dualism Even in The Irregular Sector?

2004, 80 Corrado ANDINI

Unemployment and Welfare Partecipation in a Structural VAR: Rethinking the 1990s in the United States

2004, 79 Floro Ernesto CAROLEO

Fondamenti teorici della rigidità salariale nell'ambito dei "Non Market clearing Models"

2004, 78 Adalgiso AMENDOLA, Floro Ernesto CAROLEO, Gianluigi COPPOLA Regional Disparities in Europe

2003, 77 Fernanda MAZZOTTA

Flessibilità, povertà e istruzione: un approccio Sen - istituzionale

2003, 76 Adalgiso AMENDOLA, Annamaria NESE

Mobilità intergenerale nel livello d'istruzione nella società femminile italiana ed endogenità del titolo di studio in un modello di partecipazione alla Forza Lavoro.

2003, 74 Antonio LOPES

Innovazione nel Sistema Creditizio del Mezzogiorno negli Anni Novanta

2003, 73 Sergio DESTEFANIS, Vania SENA

Public Capital and Total Factor Productivity New Evidence from the Italian Regions

2003, 72 Giuseppina AUTIERO, Bruna BRUNO

Social Preferences in Wage Bargaining: a Neocorporatist Approach

2003, 71 Gianluigi COPPOLA, Maria Rosaria GAROFALO, Fernanda MAZZOTTA Industrial Localisation and Economic Development. A Case Study 
2002, 70 Francesco GIORDANO, Fernanda MAZZOTTA

Salario di Riserva, Probabilità di Occupazione ed Efficacia dell'Istruzione Universitaria: un'Analisi sugli Studenti dell'Università di Salerno

2002, 69 Giuseppe RUSSO

Istituzioni del Mercato del Lavoro e Occupazione: dai Costi di Aggiustamento all'Appropriabilità

2002, 68 Floro Ernesto CAROLEO, Francesco PASTORE

Training Policy for Youth Unemployed in a Sample of European Countries

2002, 67 Maria Rosaria GAROFALO, Maria Rosaria SUPINO

II Disegno Normativo del Welfare Municipale in Italia come Strumento per lo Sviluppo

Economico e l'Allargamento delle Opportunità Occupazionali. Una Lettura Neoistituzionale della L. 328/00

2002, 65 Pietro SENESI

Cyclical dynamics under continuous time equilibrium

2001, 64 Marcello D'AMATO, Vincenzo GALASSO

E' la Riforma Dini Politicamente Sostenibile?

2001, 63 Sergio DESTEFANIS, Ornella Wanda MAIETTA

Assessing the Productive Efficiency of Non-Profit Organisations: a Comparative Analysis

2001, 62 Floro Ernesto CAROLEO, Francesco PASTORE

How fine targeted is ALMP to the youth long term unemployed in Italy?

2001, 61 Paolo COCCORESE

Strategic Advertising for Entry Deterrence Purposes

2001, 60 Alessandra AMENDOLA

Modelling Asymmetries in Unemployment Rate

2001, 59 Sergio DESTEFANIS

Differenziali Territoriali di Produttività ed Efficienza negli Anni '90: i Livelli e l'Andamento

2001, 58 Giuseppina AUTIERO, Fernanda MAZZOTTA

Job Search Methods: the Choice between the Public and the Private Sector

2001, 57 Giuseppina AUTIERO, Bruna BRUNO, Fernanda MAZZOTTA

A Correspondence Analysis of Labour Market Institutions

2000, 56 Giuseppina AUTIERO

Governmental Organized Learning and Coordination Problems: The case of Japan in1950s

2000, 55 Giuseppina AUTIERO, Fernanda MAZZOTTA

The Choice of Search Methods: Some Empirical Evidence from Italy

2000, 54 Giuseppe CELI

The Impact of International Trade on Labour Markets. The Case of Outward Processing Traffic between the European Union and Central Eastern European Countries. 
2000, 53 Giuseppe RUSSO, David VEREDAS

Institutional Rigidities and Employment on the Italian Labour Market: the Dynamic of the Employment in the Large Industrial Firms.

2000, 52 Floro Ernesto CAROLEO

Le Politiche per l'Occupazione in Europa: una Tassonomia Istituzionale

2000, 51 Andrew NEWELL, Francesco PASTORE

Regional Unemployment and Industrial Restructuring in Poland

1999, 50 Giuseppe CELI, Alasdair SMITH

Quality Differentiation and the Labour Market Effects of International Trade.

1999, 49 Giuseppe CELI

Vertical and Horizontal Intra-Industry Trade: What is the Empirical Evidence for the UK?

1999, 48 Cesare IMBRIANI, Filippo REGANATI

Productivity spillovers and regional differences: some evidence on the italian manufacturing sector.

1999, 47 Adalgiso AMENDOLA, Annamaria NESE

L'impatto del background familiare sul livello d'istruzione dei figli.

1998, 46 Adalgiso AMENDOLA, Annamaria NESE

Mobilità intergenerazionale nella società femminile italiana.

1998, 45 Floro Ernesto CAROLEO, Fernanda MAZZOTTA

Youth Unemployment and youth employment policies in Italy.

1997, 44 Annamaria NESE

Mobilità intergenerazionale in Italia

1997, 43 Adriana BARONE, Concetto Paolo VINCI

Fairness: un concetto relativo nell'analisi del mercato del lavoro

1997, 42 Adriana BARONE, Concetto Paolo VINCI

Wage differentials and factor intensity reversals

1997, 41 Rosa CAPOLUPO

L'ipotesi di convergenza nel recente dibattito sulle teorie della crescita

1997, 40 Rosa CAPOLUPO

Endogenous Vs exogenous models of growth: the convergenze debate

1997, 39 Fernanda MAZZOTTA, Annamaria NESE

Transizioni "In and Out" il mercato del lavoro in Italia: un'analisi microeconometrica

1997, 38 Fernanda MAZZOTTA

Disoccupazione e probabilità di occupazione in Italia: un'analisi su microdati

1997, 37 Maria Rosaria GAROFALO, Bruna BRUNO

Equivalenza istituzionale" dei modelli di contrattazione sul salario: oltre il dibattito tra 
centralizzazione e decentramento

1997, 36 Adalgiso AMENDOLA, Floro Ernesto CAROLEO, Gianluigi COPPOLA Differenziali territoriali nel mercato del lavoro e sviluppo in Italia

1996, 35 Adalgiso AMENDOLA Istituzioni e mercato del lavoro. Deregolazione, occupazione e paradigma istituzionale

1996, 33 Annamaria NESE Modelli microeconometrici per l'analisi della domanda abitativa

1996, 32 Annamaria NESE

Test semiparametrici per modelli parametrici

1996, 31 Giuseppe CELI

Vertical intra-industry trade and skill intensity in Europe: a cross sector analysis

1996, 30 Sergio DESTEFANIS

Nominal rigidities and real activity. A cross-industry analysis for Italy, 1951-93

1996, 29 Cesare IMBRIANI, Filippo REGANATI

International technology transfer into the italian manufacturing sector

1996, 28 Stefania di SERAFINO, Alberto GANDOLFI

The choice of the Government optimal procurement mechanism: the first-price sealed bid auction with one and/or two winners.

1996, 27 Raul de LUZENBERGER

Redistribution, and public debt with liquidity constraints

1996, 26 Bruno CHIARINI

Un modello VAR per la domanda di lavoro

1995, 25 Maria Rosaria CARILLO, Alberto ZAZZARO

Innovazione tecnologica e distruzione di capitale umano in un modello neo-shumpeteriano di crescita.

1995, 24 Raul de LUZENBERGER

Macroeconomia e politiche redistributive: il caso di vincoli di liquidità

1995, 23 Annamaria NESE

Tenure choice and demand for housing in Italy

1995, 22 Filippo REGANATI

La struttura delle preferenze per prodotti orizzontalmente differenziati.

1995, 21 Sergio DESTEFANIS, Michele LA ROCCA, Cosimo VITALE

Forecasting train ticket sales with linear model-based approaches and with edats

1995, 20 Stefania di SERAFINO

Bounded rationality and incomplete contracts 
1995, 19 Adalgiso AMENDOLA, Floro E. CAROLEO, Maria Rosaria GAROFALO Istituzioni, mercato del lavoro e decentramento delle decisioni.

1995, 18 Niall O'HIGGINS

Why did the youth training scheme reduce the wages of young people? A story of human capital formation, reservation wages and job offers.

1994, 17 Antonio CARDONE

Misure di efficienza: alcuni aspetti teorici

1994, 16 Maria Rosaria GAROFALO, Luisa ZANCHI

Neo-corporativismo, centralizzazione e dispersione inter-settoriale dei salari.

1994, 15 Sergio DESTEFANIS

Allowing for frequency of negotiation in the aggregate wage equation. A study for Italian manufacturing, 1973/92.

1994, 14 Marcello D'AMATO

Tariffs for a foreign industry with market power under incomplete information on demand

1994, 13 Raul DE LUZENBERGER, Cesare IMBRIANI, Giancarlo MARINI

Sustainability Issues in the process of European Integration

1994, 12 Riccardo MARSELLI, Antonio CARDONE

Interdipendenza tra regioni: un'analisi su dati di Panel

1993, 11 Adriana BARONE, Concetto Paolo VINCI

Dilemma del prigioniero e persistenza della disoccupazione involontaria

1993, 10 Maria Rosaria CARILLO

Mutamenti strutturali ed offerta di lavoro.

1993, 9 Niall O'HIGGINS

The effectiveness of YTS in Britain: an analysis of sample selection in the determination of employment and earnings

1993, 8 Giuseppe CELI

Politiche valutarie ed integrazione commerciale: l'esperienza dello SME negli anni '80

1992, 7 Paolo COCCORESE

Attività innovativa e configurazione industriale

1992, 6 Maria Rosaria GAROFALO, Gian Luigi CORINTO

La Razionalità dell'Allocazione del Tempo di Lavoro in Agricoltura. Con un'Applicazione Empirica ad un Sistema Locale attraverso la PL..

1992, 5 Adalgiso AMENDOLA, Maria SCATTAGLIA

Disoccupazione e Tassi di Attività nel Mezzogiorno

1992, 4 Floro Ernesto CAROLEO

La Disoccupazione Strutturale 
1991, 3 Giovanni URGA

Dynamic Models of Labour Demand in the Italian Industrial Sector: Theories and Evidence from Panel Data

1991, 2 Adalgiso AMENDOLA

Teoria dei Contratti Impliciti. Rigidità del Salario e Disoccupazione

1991, 1 Guido CELLA

Sulla Integrazione Produttiva Interregionale: il Caso del Mezzogiorno 
CELPE - Centro di Economia del Lavoro e di Politica Economica Università degli Studi di Salerno

ISSN 1970-4259

ISBN 978-88-95406-07-7

Depositato ai sensi di Legge 